\title{
Implementation of a sewage treatment station in the Ayapuá set in the city of Manaus
}

\section{Elen Carolina Soares Machado1, Maria do Perpétuo Socorro Lamego Vasconcelos ${ }^{2}$}

\author{
${ }^{1,2}$ Laureate International Universities (UNINORTE). Av. Joaquim Nabuco, 1270, Centro, Manaus - AM. Brasil, CEP:69020-030
}

Email: elencarolina.machado@hotmail.com

Received: June $20^{\text {th }}, 2017$

Accepted: September 25 $5^{\text {th }}, 2017$

Published: September $30^{\text {th }}, 2017$

Copyright $\odot 2016$ by authors and Institute of Technology Galileo of Amazon (ITEGAM) This work is licensed under the Creative Commons Attribution International License (CC BY 4.0).

http://creativecommons.org/licenses/by/4.0/

\begin{abstract}
The almost inexistence of sewage collection networks in the city of Manaus, as well as the serious consequences to public health and the environment, makes it necessary to establish sewage networks capable of minimizing and trying to solve such problems. The objective of this article is to implement an Sewage Treatment Plant in the Ayapuá Complex, which does not have a satisfactory sewage treatment system, has only sewage collection boxes and all household waste is disposed of directly In the igarapé of the region, without any type of suitable treatment. And located in the neighborhood of Compensa I, in the city of Manaus, in the state of Amazonas. Using a primary an Sewage Treatment Plant, with a septic tank with anaerobic filter, adopting the design for a residential complex consisting of masonry and reinforced concrete with natural filtering aggregates. The methodology has an applied nature since it seeks to solve the specific problem of a lack of sewage collection network in the city of Manaus, specifically in the western part of the Amazonian capital. Calculation tables and graphs will be used to demonstrate the feasibility of applying the mentioned method in this article. As a result the viability of the implementation of the project of the sewage treatment plant is verified, as well as the reduction of the pollution level of the wastewater in that specific region.
\end{abstract}

Keywords: Sewage Treatment Plant, Anaerobic filter, Sewage treatment.

\section{Implantação de uma estação de tratamento de esgoto no Conjunto Ayapuá na Cidade de Manaus}

\section{RESUMO}

A quase inexistência de rede coletoras de esgotos na cidade de Manaus, bem como as graves consequências à saúde pública e ao meio ambiente, faz necessária a implantação de redes de esgotos capazes de minimizar e tentar solucionar tal problemática. O presente artigo tem como objetivo a implantação de uma Estação de Tratamento de Esgotos (ETE) no Conjunto Ayapuá, que o mesmo não possui um sistema de tratamento de esgoto satisfatório, possui somente caixas coletoras de esgoto e que todos os resíduos domésticos são despejados diretamente no igarapé da região, sem nem um tipo de tratamento adequado. E localizado no bairro da Compensa I, na cidade de Manaus, no estado do Amazonas. Utilizando uma ETE primaria, com tanque séptico com filtro anaeróbio, adotando o dimensionamento para um conjunto residencial constituída de alvenaria e concreto armado com agregados naturais filtrantes. A metodologia possui natureza aplicada uma vez que procura solucionar o problema específico falta de rede de coleta de esgotos na cidade de Manaus, especificamente na zona oeste da capital amazonense. Serão utilizadas tabelas de cálculo e gráficos para demonstrar a viabilidade para a aplicação do referido método presente neste artigo. Como resultado verifica-se a viabilidade da implementação do projeto da estação de tratamento de esgotos, bem poderá ser verificada a diminuição do nível de poluição das águas despejadas naquela região específica.

Palavras Chaves: ETE, Filtro Anaeróbio, Tratamento de esgoto. 


\section{INTRODUÇÃO}

No que se refere às questões ambientais, o tratamento de esgotos assume papel preponderante para que os grandes danos cometidos pelo homem no meio ambiente sejam reduzidos sobremaneira.

Quando se trata de esgotos sanitários temos referências muito antigas que remontam o período romano, especificamente a Cloaca Máxima de Roma que data de aproximadamente 6 séculos antes de Cristo, ou seja, o tratamento de esgotos não é algo supostamente novo [1]. Sua origem remonta períodos muito anteriores ao surgimento da civilização ocidental como conhecemos hoje, o que pode ser demonstrado pela preocupação acerca dessa necessidade que perpassa as barreiras dos séculos. Com relação ao panorama brasileiro, apesar de o meio empresarial ainda considerar problemas ambientais como secundários, a partir de 1980, as organizações passaram a sofrer influência direta da regulamentação governamental, proporcionando, com isso, uma mudança progressiva em seu ambiente de negócios [2].

O maior dos problemas quando se trata do despejo de esgotos em corpo receptores, como por exemplo rios e igarapés, é o processo natural que ocorre quando do lançamento de dejetos nestes cursos d'água. A ação das bactérias acaba por retirar todo o oxigênio presente na água e determinar a qualidade da água, no entanto a capacidade de certos microrganismos para degradar substâncias orgânicas tóxicas é muito limitada [3]. Assim, a introdução de matéria orgânica em um corpo d'água resulta indiretamente no consumo de oxigênio dissolvido. Tal situação ou processo acaba por permitir que esses corpos receptores percam oxigênio o que acarreta a poluição daquelas águas e implicação relativa ao uso dessas mesmas águas [4].

As bactérias são os principais constituintes dos flocos biológicos, o equilíbrio entre bactérias formadoras de flocos e as filamentosas é determinante para que os flocos apresentem boa estrutura, compacta e robusta [5]. Quando o corpo receptor não é capaz de assimilar a grande quantidade de esgoto despejado em suas águas temos a impossibilidade da autodepuração e a provável caracterização da poluição. Sintetiza afirmando que a capacidade de assimilação do corpo d'água pode ser utilizada até um ponto aceitável e não prejudicial, não sendo admitido o lançamento de cargas poluidoras acima deste limite.

O tratamento adequado de esgoto sanitário assume papel relevante nos dias atuais, uma vez que é cada vez mais necessária a aplicação de técnicas, ainda que descentralizadas, para diminuir a baixa quantidade de esgotos sanitários no Brasil.

Assim, fica claro que há a necessidade de serem implementados métodos que possam suprir essa necessidade, para que assim, tais objetivos sejam atingidos. É importante que sejam observadas as técnicas que possam se adequar às necessidades e características de cada região [6]. O país ainda não possui uma presença significativa de consumidores verdes para que se configurem num verdadeiro estímulo à sujeição empresarial ao imperativo ecológico. Mesmo que alguns insistam em afirmar o contrário, o consumidor verde no Brasil ainda é uma incógnita, não se sabe, se ele existe de fato e em qual proporção [7].

É importante frisar as diferenças entre esgoto doméstico e esgoto industrial. É considerado esgoto doméstico o despejo líquido resultante do uso da água para higiene e necessidades fisiológicas humanas. Denomina-se esgoto industrial o despejo líquido resultante dos processos industriais, respeitados os padrões de lançamentos estabelecidos [8]. Desta forma, em termos regionais, notadamente a região das aglomerações urbanas nas grandes cidades da Amazônia constata-se a imensa quantidade de esgoto doméstico sendo lançado em diversos copos receptores, principalmente em rios e igarapés. O despejo de esgoto, seja doméstico ou industrial, nos rios e igarapés da Amazônia tem grande impacto ambiental, uma vez que muitos desses corpos receptores não possuem condições de realizar a autodepuração o que acarreta na poluição dessas águas e consequentemente a destruição do meio ambiente.

\section{REVISÃO BIBLIOGRÁFICA}

O esgoto sanitário é, basicamente, formado pela reunião de águas residuais dos usos domésticos, comerciais e institucionais, geradas, portanto, nos domicílios, bares, restaurantes, aeroportos, rodoviárias, hotéis, farmácias, shopping centers, hospitais, postos de saúde, escolas, casas de detenção, repartições públicas, etc.[9]. Além destes locais, onde o uso da água e geração dos esgotos é feito em aparelhos sanitários como vasos sanitários, chuveiros, pias, mictórios, bidês, tanques, máquinas de lavar pratos e roupas e ralos para captação de águas de lavagens de áreas cobertas, fazem parte do volume total de esgoto sanitário gerado num município, os despejos industriais, previamente tratados e enquadrados aos padrões de lançamento na rede pública, e as parcelas de águas provenientes de precipitações pluviométricas e de lençóis subterrâneos que conseguem adentrar à rede pública de coleta e veiculação de esgotos por locais e pontos singulares do sistema impossibilitados de serem perfeitamente estanques, tais como: tampas e paredes de caixas de passagem, inspeção e poços de visita, conexões entre tubulações e até mesmo, ligações clandestinas.

Importante frisar que a população tem o direito não somente ao tratamento de esgotos, mas principalmente ao saneamento ambiental que visa o aproveitamento do meio ambiente para obter um bom saneamento, pois possui alta potencialidade no alcance do desenvolvimento sustentável [10].

Assim, as características dos esgotos são em função dos usos à qual foi submetida, e que variam como clima, situação social e econômica e hábitos da população. Podendo ser físicos, químicos e biológicos. Seus parâmetros de qualidade é o que definem do esgoto sendo eles: turbidez, cor, $\mathrm{pH}$, sólidos sedimentares ou outros parâmetros [11].

\section{II.1 A NOVA ESTAÇÃO DE TRATAMENTO DE ESGOTOS}

As Estações de Tratamento de Esgoto (ETE's) geram diversos subprodutos, dentre eles o lodo, que é responsável por um elevado custo operacional em seu tratamento, transporte e disposição final. Cabe ressaltar que o tratamento de lodo diz respeito basicamente ao seu pré-condicionamento para um adequado destino final [12]. O tratamento tem então o objetivo de digestão, estabilização, redução de volume, secagem, higienização, dentre outros. Enquanto a disposição final é basicamente uma forma de descarte.

A escolha da ETE no novo milênio não se restringe apenas às exigências ambientais, de saúde pública, estéticas ou legais. Considera igualmente exigências tecnológicas, exigências de economia e mesmo os anseios da comunidade [13].

Há de se considerar, além dos outros aspectos, os anseios da comunidade como fator relevante para a implantação de uma ETE. Ocorrem situações em que todas as exigências técnicas, ambientais e econômicas já estão sanadas, no entanto, a comunidade do local onde se vai implantar a estação de tratamento de esgotos se coloca contra o projeto. Neste sentido, a análise para a implantação de uma ETE perpassa esses aspectos e outros de cunho de saúde pública e estética para adentrar no campo político. É importante que o projetista observe, também, essas variáveis importantes na consecução do projeto de uma ETE. 
O lodo necessita de um tratamento específico visando corrigir três características indesejáveis do resíduo, tais quais; a instabilidade biológica: o método mais comum para reduzir o teor de material orgânico biodegradável (presente no lodo primário e no lodo aeróbico) é a digestão anaeróbica, sendo também utilizada a digestão aeróbica; a baixa qualidade higiênica: no esgoto sanitário há grande variedade de vírus, bactérias, protozoários, ovos de nematóides e helmintos; o grande volume: como a concentração de sólidos no lodo é baixa, seu volume grande, tornando necessária uma etapa de redução de teor de água [14], tal processo anaeróbio pode durar meses e anos [15].

Outro aspecto ligado ao processo de tratamento de esgoto, que influi na produção de lodo é a eficiência do processo de pré-tratamento, principalmente se o efluente carrear altos teores de areia e outros materiais de origem mineral [16].

\section{II.2 DELIMITAÇÃO DA ÁREA DE ESTUDO}

A área física a ser utilizada para a construção da ETE possui $460 \mathrm{~m}^{2}$ e está localizada ao lado do Bloco Q1 do Conjunto Ayapuá.

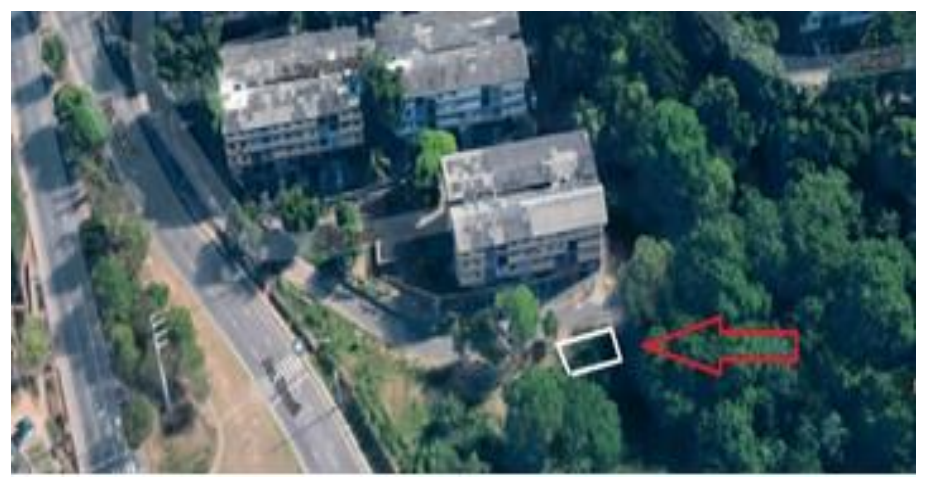

Figura 1: Local de Implantação da ETE

Fonte: Adaptado [17].

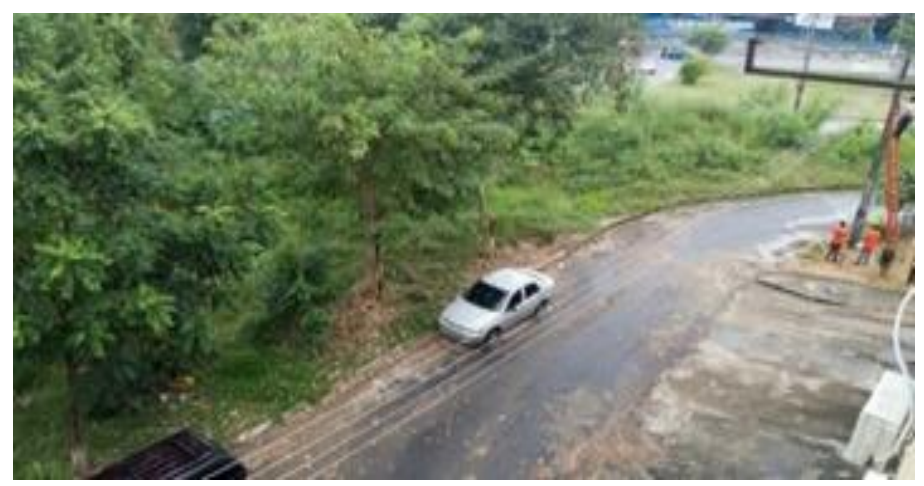

Figura 2: Vista aérea do local de instalação.

Fonte: Autores, (2017).

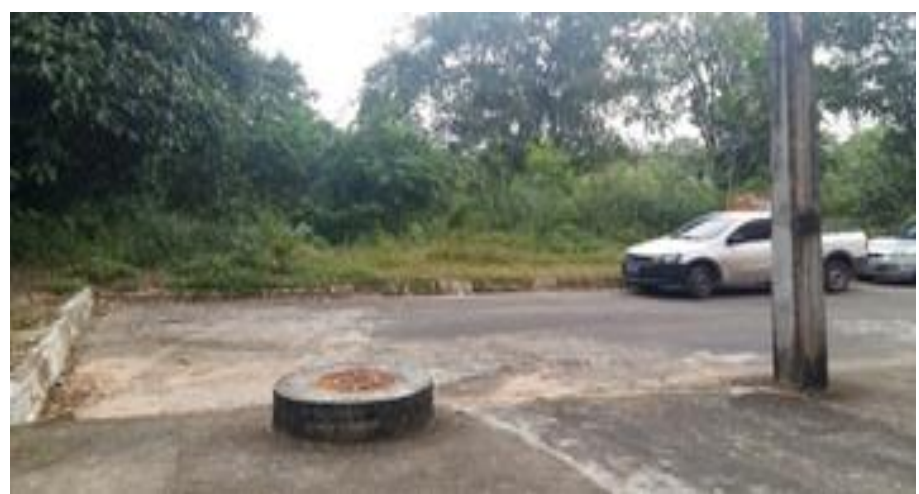

Figura 3: Vista do local de instalação com caixa de passagem.

Fonte: Autores, (2017).
O Conjunto Residencial Ayapuá está implantado em uma área de 120.959,20 m² e está localizado entre a Avenida Coronel Teixeira e a Avenida Brasil, no bairro da Compensa. A área construída do conjunto, em alvenaria, ocupa exatos $16.690,94 \mathrm{~m}^{2}$. O residencial limita-se ao Norte com a Avenida Coronel Teixeira, ao Sul com a Comissão Regional de Obras da $12^{\circ}$ Região, a oeste com a Avenida Brasil e a leste com a Área Militar Oeste.

Com o passar dos anos e o crescimento desordenado, a Compensa se tornou o quarto bairro mais populoso de Manaus, no entanto, devido, principalmente, à maneira como se deu sua origem, foi se erguendo sobre a desorganização e falta de ordenamento que marcaram os primeiros dias de sua ocupação [18]. Não obstante todos esses problemas e principalmente a falta de saneamento básico em mais de $90 \%$ da cidade de Manaus, o que se reflete também nas taxas de saneamento básico em toda a zona oeste de Manaus, o bairro da Compensa cresceu e em sua área comporta, inclusive, as sedes do poder político amazonense, notadamente, as sedes da :Prefeitura Municipal de Manaus e sede do Governo do Estado do Amazonas, além de possuir feiras, mini shoppings, vasta área comercial, hospitais e uma maternidade [19].

\section{MATERIAIS E MÉTODOS}

\section{III.1 HORIZONTE DO PROJETO}

O projeto deverá considerar compatibilidade com metas de atendimento de vazão e qualidade do tratamento de esgotos, dentro de horizonte de planejamento máximo de 30 anos.

\section{III.2 VAZÕES DE ESGOTO EFLUENTE A ETE}

Para se determinar as vazões a serem levadas em consideração no projeto deve-se ter em mente os parâmetros predeterminados pela Manaus Ambiental no que se refere a projetos de abastecimento de água e coleta de esgoto.

No entanto, de forma opcional poderão ser adotados os seguintes critérios:

- Para o cálculo da vazão média anual de esgoto produzido deverá ser estimada com base no per capita de água de abastecimento e em coeficiente de retorno esgoto/água igual a 1;

- Para o cálculo da vazão média, não devem ser consideradas as vazões de infiltração (já incorporadas no coeficiente esgoto/água igual a 1);

- A vazão do dia de maior produção de esgoto deve ser considerada igual a 1,2 a vazão média anual; esta vazão deve ser adotada no cálculo das unidades de processo;

- A vazão máxima de esgoto deve ser considerada igual a 1,5 vezes a vazão média do dia de maior produção de esgotos e adotada para dimensionamentos hidráulicos.

\section{III.3 CARACTERÍSTICAS QUALITATIVAS DO ESGOTO EFLUENTE À ETE}

As características qualitativas médias do esgoto bruto afluente a ETE a serem adotadas devem ser derivadas dos seguintes índices:

- Remoção de DBO 5 dias, $20^{\circ} \mathrm{C}$ maior ou igual a $80 \%$ ou concentração de DBO menor que $60 \mathrm{mgO} 2 / \mathrm{L}$;

Concentração de nitrogênio total menor ou igual a 20 mgN/L Parâmetro Padrão do Afluente DBO 54g/hab/dia; NTotal 10gN/hab/dia; PTotal 1,8gP/hab/dia e Coli Termo Tolerantes 107 org $/ 100 \mathrm{~mL} 8$. 
Tabela 1: Parâmetro padrão do esgoto bruto efluente.

\begin{tabular}{lc}
\hline & Parâmetro Padrão do Efluente \\
DBO & $54 \mathrm{~g} / \mathrm{hab} / \mathrm{dia}$ \\
NTotal & $10 \mathrm{gN} / \mathrm{hab} / \mathrm{dia}$ \\
PTotal & $1,8 \mathrm{gP} / \mathrm{hab} / \mathrm{dia}$ \\
Coli Termo Tolerantes & $107 \mathrm{org} / 100 \mathrm{~mL}$ \\
\hline
\end{tabular}

Fonte: Autores, (2017).

\section{III.4 METAS DE QUALIDADE PARA O EFLUENTE DAS ETES}

Deverão ser considerados os seguintes parâmetros: DBO 5dias, $20^{\circ} \mathrm{C}(\mathrm{mgO} 2 / \mathrm{L})$; Nitrogênio Total (mgN/L); Fósforo Total (mgP/L); Coliformes Termotolerantes (org/100mL).

No que tange aos padrões de emissão, a qualidade do efluente tratado da ETE deverá ser suficiente para atender aos padrões de emissão estabelecidos nos artigos 21, 22 e 23 da Resolução CONAMA n ${ }^{\circ} 430 / 2011$, ou versões mais recentes, de forma que obedeça aos seguintes parâmetros:

- PH entre 5 e 9;

- Temperatura: inferior a $40^{\circ} \mathrm{C}$, sendo que a variação de temperatura do corpo receptor não deverá exceder a $3^{\circ} \mathrm{C}$ no limite da zona de mistura;

- Materiais sedimentáveis: até $1 \mathrm{~mL} / \mathrm{L}$ em teste de 1 hora em cone Inmhoff. Para o lançamento em lagos e lagoas, cuja velocidade de circulação seja praticamente nula, os materiais sedimentáveis deverão estar virtualmente ausentes;

- Demanda Bioquímica de Oxigênio-DBO 5 dias, $20^{\circ} \mathrm{C}$ : máximo de $120 \mathrm{mg} / \mathrm{L}$, sendo que este limite somente poderá ser ultrapassado no caso de efluente de sistema de tratamento com eficiência de remoção mínima de $60 \%$ de DBO, ou mediante estudo de autodepuração do corpo hídrico que comprove atendimento às metas do enquadramento do corpo receptor. $100 \mathrm{mg} / \mathrm{L}$;

- Substâncias solúveis em hexano (óleos e graxas) até

- Ausência de materiais flutuantes.

Acerca dos Padrões de Qualidade No cálculo dos padrões de emissão para atendimento aos limites e condições fixadas para as águas dos corpos receptores, na legislação federal, deverão ser observadas as seguintes diretrizes: vazão média do dia de maior produção de efluente tratado; determinação analítica de amostra representativa das águas do corpo receptor potencial em período de baixa vazão.

O cálculo dos valores máximos dos parâmetros qualitativos deverá ser feito com base nos valores acima e na vazão de referência do corpo receptor na seção de lançamento. A vazão de referência do corpo receptor do efluente da ETE deverá ser calculada com base no que determina o artigo $2^{\circ}-$ inciso XXXVI da Resolução CONAMA 357/2005.

\section{RESULTADOS E DISCUSSÕES}

\section{IV.1 MEMORIAL DESCRITIVO DA ESTAÇÃO DE TRATAMENTO DE ESGOTO}

Este memorial visa apresentar os critérios adotados para o dimensionamento do sistema de esgotamento sanitário e desinfecção do efluente tratado, bem como as normas que nortearam o desenvolvimento destes projetos e suas especificações. $\checkmark$ ABNT NBR 7229/ 93 - Projeto, construção e operação de sistemas de tanques sépticos [20];

$\checkmark$ ABNT NBR 13969/ 97 - Tanques sépticos - Unidades de tratamento complementar e disposição final dos efluentes líquidos - Projeto, construção e operação [21].

\section{IV.2 CAIXAS DE INSPEÇÃO}

Serão em alvenaria de tijolos maciços, revertidos internamente com cimento alisado. Terão as dimensões de $100 \mathrm{x}$ $100 \mathrm{~cm}$ (medidas internas), profundidades variáveis (a fim de atender às necessidades de declividade dos sub coletores a elas ligadas), com tampas de concreto armado, e dotadas de canaletas no fundo, (direcionadas no sentido do fluxo do esgoto). A profundidade mínima será de $40 \mathrm{~cm}$.

\section{IV.3 SUB COLETORES E COLETORES}

PVC Série Normal, com diâmetros e declividades indicados no projeto. Os esgotos sanitários recolhidos do prédio serão encaminhados para os dois conjuntos Tanque Séptico + Filtro Anaeróbio, sendo uma para a primeira etapa com 960 contribuintes e a segunda etapa para 540 contribuintes e está estação de tratamento de esgoto vai está localizada no final do terreno

Seguem abaixo os dimensionamentos destes dois conjuntos de componentes:

Tanque séptico: será em executada em tijolos cerâmico e rebocada, assim com o fundo e piso impermeabilizado onde recebera os dejetos. $\mathrm{O}$ filtro recebera a água que será tratada por meios de filtros em areia, brita e carvão vegetal, e será jogada no igarapé localizado na Avenida Brasil com 95\% de pureza, conforme a norma NBR 7229/ 93.

\section{IV.3.1 DESCRIÇÃO GERAL DAS INSTALAÇÕES}

Devido ao tamanho do Conjunto Ayapuá a Estação de Tratamento de Esgotos será composta de dois conjuntos de tanques sépticos e filtro anaeróbio, para efeitos deste projeto sendo denominadas ETE1 e ETE2.

Essas instalações destinam-se a coletar as águas residuais e encaminhá-las às caixas de inspeção $(\mathrm{CE})$ e daí às respectivas caixas coletoras de esgoto públicas.

Teve-se em conta, no traçado e disposição dos seus elementos, o rápido escoamento dos despejos e a perfeita vedação dos gases da rede primária. Será executado conforme o Sistema de Tratamento Ecológico de Esgotos.

Teve-se em conta, no traçado e disposição dos seus elementos, o rápido escoamento dos despejos e a perfeita vedação dos gases da rede primária. Os esgotos primários e secundários serão dirigidos diretamente às caixas de inspeção; os esgotos das pias de cozinha e máquinas de lavar louças, às caixas de gordura; os esgotos das máquinas e tampas de lavar roupas, às caixas sifonadas especiais. Os dois sistemas - esgotos sanitários e de águas pluviais - serão distintos e não se misturam em nenhum ponto nas respectivas redes. Nas instalações sanitárias, os tubos e conexões serão em PVC rígido para esgoto soldável, da marca Tigre ou similar. Canais de descarga e de esgoto, Tubos de diâmetro $100 \mathrm{~mm}$ : 1,0\%, Tubos de diâmetro 100 ou $150 \mathrm{~mm}: 1,0$ $\%$, Sub coletores ou coletores prediais: $1,5 \%$. O recobrimento mínimo das tubulações no solo será de $50 \mathrm{~cm}$ e nas áreas de tráfego de veículos serão envolvidos por uma camada de cimento. A declividade será uniforme entre as sucessivas caixas de inspeção, não se permitindo depressões que possam formar depósitos no interior das canalizações. Todas as mudanças de 
direção nas tubulações de esgoto deverão ser executadas com dispositivos de inspeção. Desta forma, temos os seguintes materiais: Tubulações de esgoto primário: PVC rígido, com ponta e bolsa com bitola, nos diâmetros 100 e 150; Tubulações de esgoto secundário: PVC rígido, com ponta e bolsa com soldável, diâmetro $100 \mathrm{~mm}$.

\section{IV.4 MEMORIAL DE CÁLCULO}

Nas tabelas 2 e 3, juntamente com os quadros 1, 2, 3 e 4, abaixo, exibem o memorial de cálculo e, que tem por objetivo descrever as dimensões e a capacidade do Tanque Séptico e um Filtro Anaeróbio (ETE), em concreto armado, impermeabilizado, segundo os procedimentos da NBR 7229 de setembro de 1993 , tendo como efluente final a rede de coleta de aguas pluviais existente no local próximo ao local, e a manutenção eventual será feita com carro limpa fossa. O local é desprovido de rede pública de esgoto sanitário. A tabela 2, específica sobre a contribuição diária de despejos orgânicos para cada tipo de prédio, sendo ele residencial, comercial ou público, conforme os seus ocupantes ou seu tráfego de circulação por pessoas. No caso deste artigo, os prédios são de apartamentos, como está em destaque na tabela.

Tabela 1: Contribuição diária de despejos e de carga orgânica por tipo de prédio e de ocupantes

\begin{tabular}{|c|c|c|c|}
\hline Prédio & Unidade & Esgoto $[\mathrm{C}]$ & Lodo Fresco[Lf] \\
\hline 1 - Ocupantes Permanentes & & & 1 \\
\hline Hospitais & leito & 250 & 1 \\
\hline Apartamentos & pessoa & 200 & 1 \\
\hline Residências & pessoa & 150 & 1 \\
\hline Escolas-internatos & pessoa & 150 & 1 \\
\hline Casas Populares rurais & pessoa & 150 & 1 \\
\hline Hotel-sem cozinha e lavanderia & pessoa & 120 & 1 \\
\hline Alojamentos provisórios & pessoa & 80 & 1 \\
\hline 2 - Ocupantes temporários & pessoa & & \\
\hline Fábrica em geral & operário & 70 & 0,3 \\
\hline Escritórios & pessoa & 50 & 0,2 \\
\hline Edifícios públicos ou comerciais & pessoa & 50 & 0,2 \\
\hline Escolas-externatos & pessoa & 50 & 0,2 \\
\hline Restaurantes e similares & Refeição & 25 & 0,1 \\
\hline Cinema, teatros e templos & lugar & 2 & 0,02 \\
\hline
\end{tabular}

Já na tabela 3, demonstra a contribuição diária de detenção dos despejos conforme litros por dia em um período determinado por horas e dias.

Tabela 2: Período de detenção dos despejos, por faixa de contribuição diária.

\begin{tabular}{|rccl|}
\hline \multicolumn{4}{|c|}{ PERÍODO DE DETENÇÃ̃ (T) } \\
\hline Contribuição [litros/dia] & horas & dias [T] \\
\hline até & 6000 & 24 & 1 \\
\hline $\mathbf{6 0 0 0}$ & 7000 & 21 & 0,875 \\
\hline $\mathbf{7 0 0 0}$ & 8000 & 19 & 0,79 \\
\hline $\mathbf{8 0 0 0}$ & 9000 & 18 & 0,75 \\
\hline $\mathbf{9 0 0 0}$ & 10000 & 17 & 0,71 \\
\hline $\mathbf{1 0 0 0 0}$ & 11000 & 16 & 0,67 \\
\hline $\mathbf{1 1 0 0 0}$ & 12000 & 15 & 0,625 \\
\hline $\mathbf{1 2 0 0 0}$ & 13000 & 14 & 0,585 \\
\hline $\mathbf{1 3 0 0 0}$ & 14000 & 13 & 0,54 \\
\hline acima de & 14000 & 12 & 0,5 \\
\hline
\end{tabular}

Fonte: Autores, (2017). 
Nos quadros 1 e 2, apresentam o cálculo para a etc.; além dos cálculos e dimensões do filtro que ajudará nesse confecção do tanque séptico de apenas uma câmara de ETE, processo de descontaminação da ETE.

mostrando os coeficientes de volume, número de contribuintes e

Tabela 4: Cálculo do Tanque Séptico e filtro anaeróbio - ETE 01.

\section{CÁLCULO DA TANQUE SÉPTICO DE}

CÂMARA ÚNICA - ETE 01

Formula: $\mathrm{V}=1000+\mathrm{n}(\mathrm{CT}+\mathrm{K} \mathrm{Lf})$

Onde:

$\mathrm{V}=$ Volume

$\mathrm{N}=$ Número de contribuintes

$\mathrm{C}=$ Contribuição de despejos, em litro/pessoa $\mathrm{x}$ dia

COEFICIENTES

960

200

$\mathrm{T}=$ Tempo em dias

0,5

$\underline{\underline{k}}=$ taxa de acumulação de lodo em dias

1,8

If $=$ Lodo fresco

$$
\mathrm{V}=1000+\mathrm{n}(\mathrm{CT}+\mathrm{K} \mathrm{Lf})
$$

(valor adotado para o cálculo do tanque foi $=$

Fonte: Autores, (2017).

Tabela 5: Cálculo do Tanque Séptico e filtro anaeróbio - ETE 01.

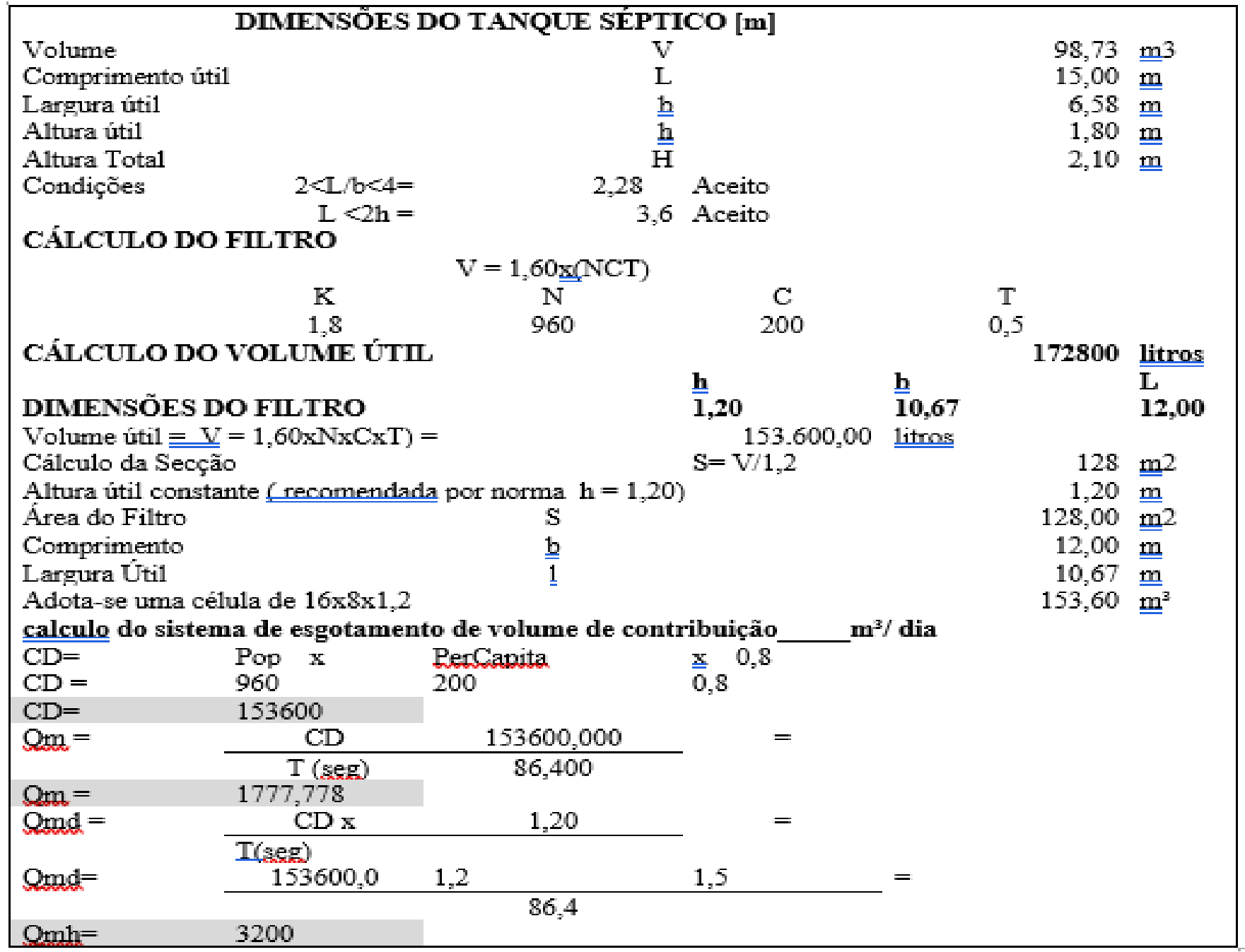

Fonte: Autores, (2017).

Nas tabelas 6 e 7, apresentam as mesmas características dos quadros 4 e 5, porém nesse caso, o cálculo para a confecção do tanque séptico de apenas uma câmara é para um resíduo diferenciado de ETE, demonstrado como ETE 2. Também apresenta os coeficientes de volume, número de contribuintes e etc.; além dos cálculos e dimensões do filtro que ajudará nesse processo de descontaminação da ETE. 
Tabela 6: Cálculo do Tanque Séptico e filtro anaeróbio - ETE 02.

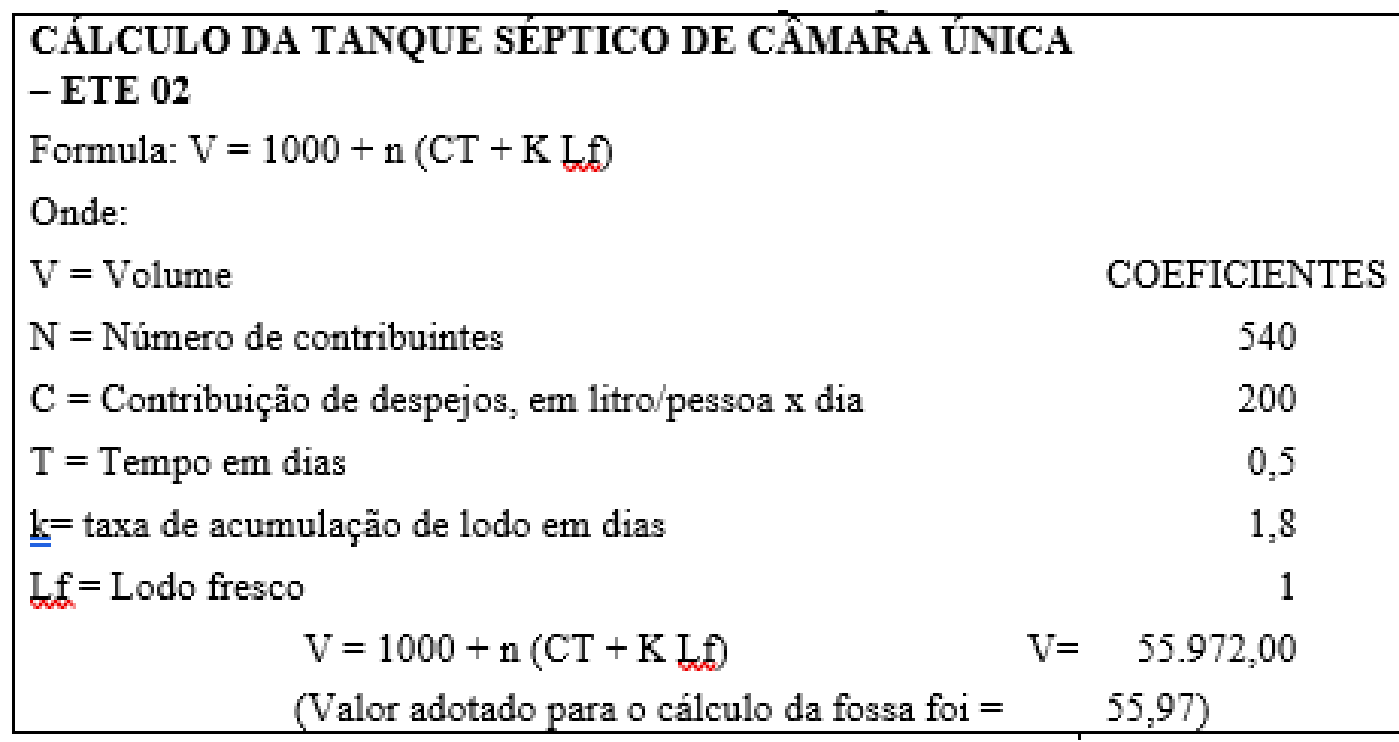

Fonte: Autores, (2017).

Tabela 7: Cálculo do Tanque Séptico e filtro anaeróbio - ETE 02.

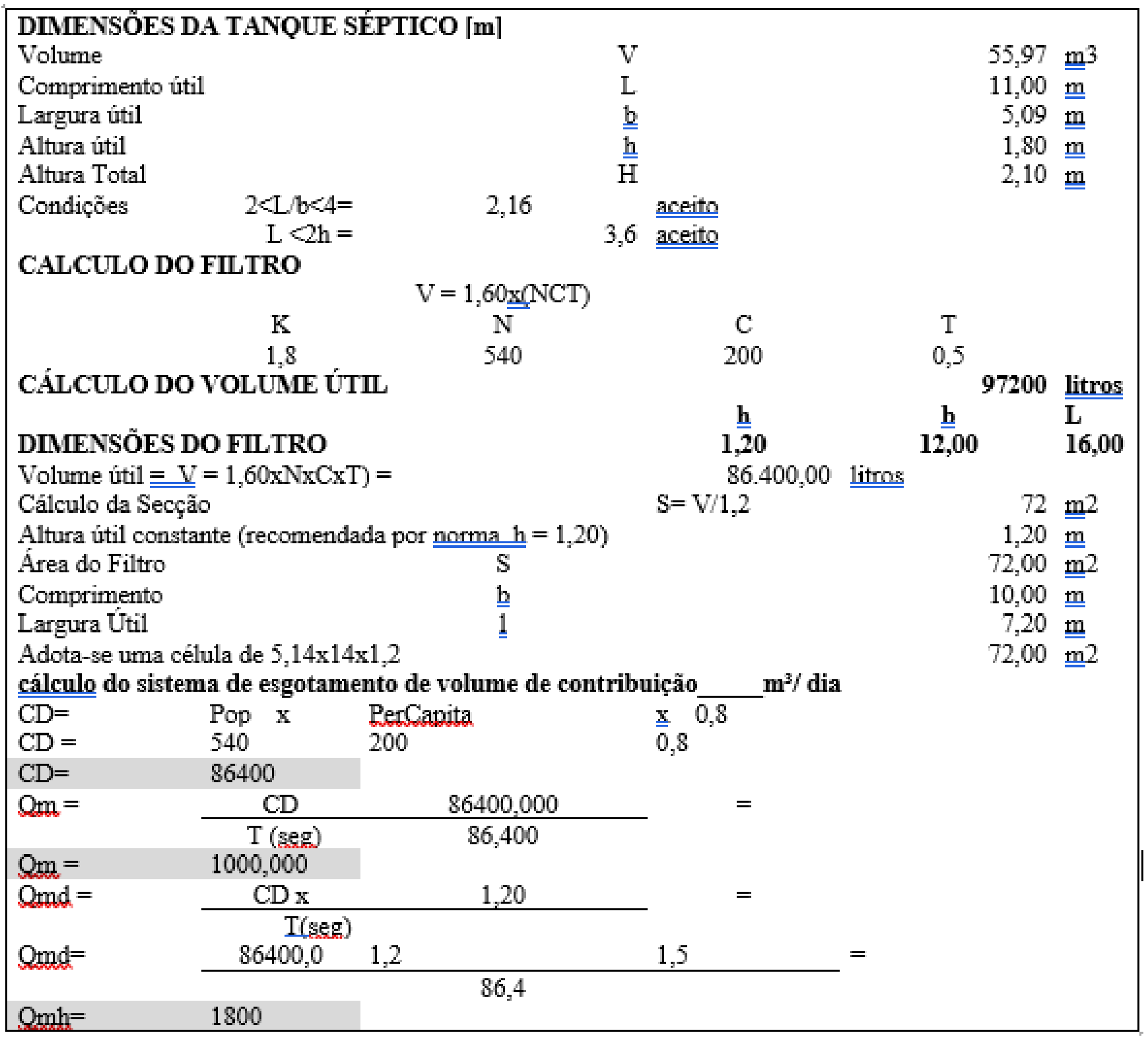

Fonte: Autores, (2017). 


\section{IV.5 CRONOGRAMA DE ATIVIDADES}

O período planejado para a execução, desde o início até seu término, do projeto de implantação da Estação de Tratamento de Esgotos compreende exatos 60 dias e se divide em: Serviços Técnicos, Serviços Preliminares, Estruturas, Instalações Hidro sanitárias e serviços complementares. De acordo com o SEBRAE - Serviço Brasileiro de Apoio às Micro e Pequenas Empresas: O cronograma é a disposição gráfica do tempo que será gasto na realização de um trabalho ou projeto, de acordo com as atividades a serem cumpridas. Serve para auxiliar no gerenciamento e controle deste trabalho, permitindo de forma rápida a visualização de seu andamento.

O período para a execução do projeto de implantação da estação de tratamento de esgoto no conjunto Ayapuá é de 60 (sessenta) dias, de acordo com a figura 4 que apresenta o gráfico do cronograma.

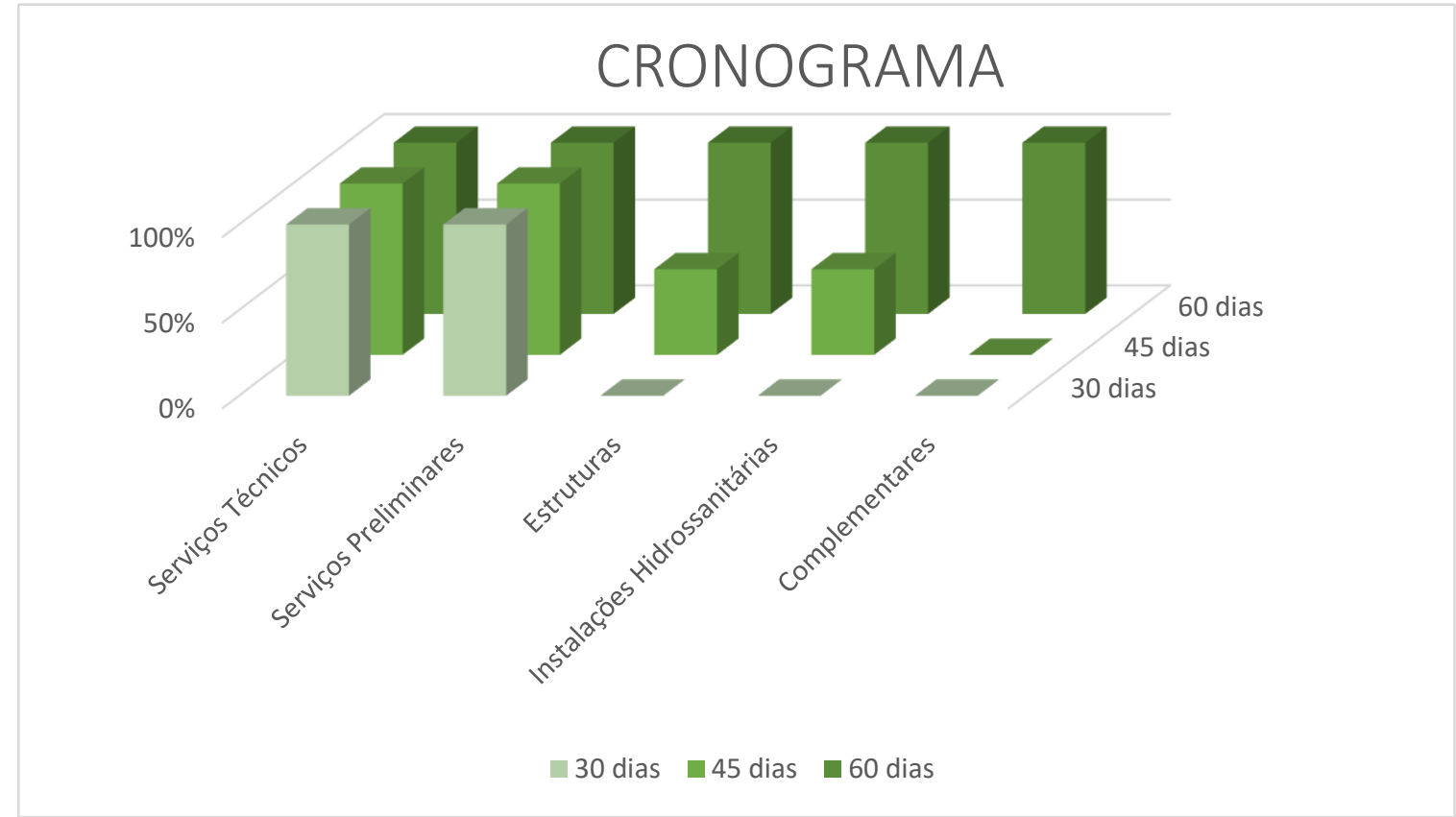

Figura 4: Gráfico do Cronograma de Atividades em 30, 45 e 60 dias.

Fonte: Autores, (2017).

\section{IV.6 CUSTO DE IMPLANTAÇÃO DO PROJETO}

Claramente existem algumas perguntas que devem ser respondidas, tais como, qual a duração das atividades, quanto período de tempo necessário para se alcançar o final do projeto (produto/serviço), qual a sequência e a dependência entre as atividades etc. De uma forma geral a duração de um projeto é calculada a partir da data zero de início das atividades, para depois ser estabelecidas a data real de início, as fases intermediárias e a data final prevista. [22]. Neste caso, o período planejado para a execução, desde o início até seu término, do projeto de implantação da Estação de Tratamento de Esgotos compreende exatos 60 dias e se divide em: Serviços Técnicos, Serviços Preliminares, Estruturas, Instalações Hidro sanitárias e serviços complementares. Inicialmente, a estimativa para a realização de serviços técnicos, que compreendem a limpeza manual do terreno; a execução do canteiro de obra em chapa de madeira compensado; locação convencional de gabarito de tábuas corridas. Estas ações correspondem ao percentual de 9,79\% (nove vírgula setenta e nove por cento) do tempo total para a execução da obra, ao mesmo tempo que tem custo estimado em $\mathrm{R} \$$ 11.969,60 (onze mil, novecentos e sessenta e nove reais e sessenta centavos).

Tabela 9: Valores dos serviços técnicos de execução da obra.

\begin{tabular}{|l|l|c|c|c|c|}
\hline ITEM & \multicolumn{1}{|c|}{ DESCRIÇÃO } & UNID. & QUANT. & PREÇO UNITÁRIO (R\$) & PREÇO TOTAL (R\$) \\
\hline $\mathbf{1}$ & SERVIÇOS TÉCNICOS & & & $\mathbf{1 1 . 9 5 9 , 6 0}$ \\
\hline 1.1 & $\begin{array}{l}\text { Limpeza manual do terreno (c/ raspagem } \\
\text { superficial). }\end{array}$ & $\mathrm{M}^{2}$ & $1.000,00$ & 3,440 & $3.440,00$ \\
\hline 1.2 & $\begin{array}{l}\text { Execução do canteiro de obra em chapa } \\
\text { de madeira compensado. }\end{array}$ & $\mathrm{M}^{2}$ & 25,00 & 320,00 & $8.000,00$ \\
\hline 1.3 & $\begin{array}{l}\text { Locação convencional de obra, através de } \\
\text { gabarito de tábuas corridas }\end{array}$ & $\mathrm{M}^{2}$ & 120,00 & 4,33 & 519,60 \\
\hline
\end{tabular}

Fonte: Autores, (2017). 
Os serviços que compreendem a escavação e carga material de $1^{\mathrm{a}}$ categoria, utilizando trator de esteira, bem como o uso de retroescavadeira sobre rodas com carregadeira; ou seja, os serviços preliminares para a execução da obra perfazem o percentual de 5,89\% (cinco vírgulas oitenta e nove por cento) e tem custo estimado em $\mathrm{R} \$ 7.200,00$ (sete mil e duzentos reais).

Tabela 10: Valores dos serviços preliminares de execução da obra.

\begin{tabular}{|l|l|c|c|c|c|}
\hline ITEM & \multicolumn{1}{|c|}{ DESCRIÇÃO } & UNID. & QUANT. & PREÇO UNITÁRIO (R\$) & PREÇO TOTAL (R\$) \\
\hline 02 & SERVIÇOS PRELIMINARES & & & & $\mathbf{7 . 2 0 0 , 0 0}$ \\
\hline 2.1 & $\begin{array}{l}\text { Escavação e carga material 1a categoria, } \\
\text { utilizando trator de esteiras. }\end{array}$ & $\mathrm{M}^{3}$ & 800,00 & 5,50 & $4.400,00$ \\
\hline 2.2 & $\begin{array}{l}\text { Retroescavadeira sobre rodas com } \\
\text { carregadeira, potência, peso operacional } \\
\text { mín. 6.570kg, profundidade escavação } \\
\text { máx. 4,37m. }\end{array}$ & HR & 20,00 & 140,00 & $2.800,00$ \\
\hline
\end{tabular}

Fonte: Autores, (2017).

Os serviços estruturais da obra, obviamente com o todo o material necessário para a consecução da obra, a saber, concreto, armações de aço, alvenaria de vedação, emboço, material filtrante, etc., consistirão na maior parte da porcentagem para a consecução da obra, perfazendo, portanto, 50,83\% (cinquenta vírgula oitenta e três por cento) desta. $\mathrm{O}$ custo estimado desta etapa é de $\mathrm{R} \$ 62.115,77$ (sessenta e dois mil, cento e quinze reais e setenta e sete centavos).

Tabela 11: Valores dos serviços para a estrutura da obra.

\begin{tabular}{|c|c|c|c|c|c|}
\hline ITEM & DESCRIÇÃO & UNID. & QUANT. & $\begin{array}{l}\text { PREÇO UNIT. } \\
(\mathbf{R} \$) \\
\end{array}$ & $\begin{array}{l}\text { PREÇO TOTAL } \\
(\mathbf{R} \$) \\
\end{array}$ \\
\hline $\mathbf{0 3}$ & ESTRUTURAS & & & & $62.115,77$ \\
\hline 3.1 & $\begin{array}{l}\text { Concreto fck=20 mpa, virado em betoneira, } \\
\text { sem lançamento. }\end{array}$ & $\mathrm{M}^{2}$ & 120,00 & 380,00 & $45.600,00$ \\
\hline 3.2 & $\begin{array}{l}\text { Forma tábua para concreto em fundação c/ } \\
\text { reaproveitamento. }\end{array}$ & $\mathrm{M}^{2}$ & 60,00 & 25,00 & $1.500,00$ \\
\hline 3.3 & Armação aço ca-50 p/ 1,0m³ de concreto. & M & 8,00 & 412,00 & $3.296,00$ \\
\hline 3.4 & $\begin{array}{l}\text { Alvenaria de vedação de blocos cerâmicos } \\
\text { furados na horizontal de } 9 \times 19 \times 19 \mathrm{~cm} \\
\text { (espessura } 9 \mathrm{~cm} \text { ) e argamassa de } \\
\text { assentamento com preparo em betoneira. }\end{array}$ & $\mathrm{M}^{2}$ & 119,57 & 36,05 & $4.310,49$ \\
\hline 3.5 & $\begin{array}{l}\text { Chapisco aplicado tanto em pilares e vigas } \\
\text { de concreto como em alvenarias de paredes } \\
\text { internas, com colher de pedreiro. argamassa } \\
\text { traço } 1: 3 \text { com preparo manual. af_06/2014. }\end{array}$ & $\mathrm{M}^{2}$ & 239,00 & 2,77 & 662,03 \\
\hline 3.6 & $\begin{array}{l}\text { Emboço, em argamassa traço } 1: 2: 8, \text { preparo } \\
\text { mecânico com betoneira } 4001 \text {, aplicado } \\
\text { manualmente em faces internas de paredes } \\
\text { de ambientes com área menor que } 5 \mathrm{~m}^{2}, \\
\text { espessura de } 20 \mathrm{~mm} \text {, com execução de } \\
\text { taliscas. af_06/2014. }\end{array}$ & $\mathrm{M}^{2}$ & 239,00 & 12,00 & $2.868,00$ \\
\hline 3.7 & $\begin{array}{l}\text { Material filtrante - colocação de areia nos } \\
\text { filtros }\end{array}$ & $\mathrm{M}^{3}$ & 25,00 & 64,08 & $1.602,00$ \\
\hline 3.8 & $\begin{array}{l}\text { Material filtrante - carvão mineral, grão } \\
\text { variando de } 0,8 \text { ate } 1,1 \mathrm{~mm} \text {, uniformidade } \\
\text { menor que } 1,7 \mathrm{~mm} \text {. }\end{array}$ & $\mathrm{M}^{3}$ & 15,00 & 25,00 & 375,00 \\
\hline 3.9 & $\begin{array}{l}\text { Material filtrante - forn.e enchimento c/ } \\
\text { brita no. } 4 .\end{array}$ & $\mathrm{M}^{3}$ & 25,00 & 76,09 & $1.902,25$ \\
\hline
\end{tabular}

Fonte: Autores, (2017).

As instalações hidro sanitárias constituem a segunda maior parte da obra, consistem em instalação de caixas coletoras, tubulação, tampa de concreto, etc. Esta etapa se constitui em
$33,31 \%$ (trinta e três vírgulas trinta e um por cento) do total da obra e possui custo estimado em $\mathrm{R} \$ 40.705,70$ (quarenta mil, setecentos e cinco reais e setenta centavos). 
Machado \& Vasconcelos, ITEGAM-JETIA. Vol. 03, № 11, pp.85-95. Setembro, 2017.

Tabela 12: Valores dos serviços para as instalações hidrosanitárias.

\begin{tabular}{|c|c|c|c|c|c|}
\hline ITEM & DESCRIÇÃO & UNID. & QUANT. & $\begin{array}{c}\text { PREÇO } \\
\text { UNIT. (R\$) }\end{array}$ & $\begin{array}{c}\text { PREÇO } \\
\text { TOTAL (R\$) }\end{array}$ \\
\hline 04 & INSTALAÇÕES HIDROSSANITÁRIAS & & & & 40.705,70 \\
\hline 4.1 & $\begin{array}{l}\text { Caixa coletora, } 1,20 \times 1,20 \times 1,50 \mathrm{~m} \text {, com fundo e tampa de } \\
\text { concreto e parede. }\end{array}$ & UN & 25,00 & $1.248,00$ & $31.200,00$ \\
\hline 4.2 & $\begin{array}{l}\text { Curva } 45^{\circ}, \text { pvc, soldável, dn } 100 \mathrm{~mm} \text {, instalado em } \\
\text { prumada de água. }\end{array}$ & UN & 26,00 & 32,00 & 832,00 \\
\hline 4.3 & $\begin{array}{l}\text { Tubo pvc, serie normal, esgoto predial, dn } 150 \mathrm{~mm} \text {, } \\
\text { fornecido e instalada. }\end{array}$ & M & $1.542,00$ & 5,05 & $7.787,10$ \\
\hline 4.4 & $\begin{array}{l}\text { Tubo pvc, serie normal, esgoto predial, dn } 100 \mathrm{~mm} \text {, } \\
\text { fornecido e instalada. }\end{array}$ & M & 341,00 & 2,60 & 886,60 \\
\hline
\end{tabular}

Fonte: Autores, (2017).

A parte final da obra se constitui de execução de passeio (calçada) em concreto, conjunta de dilatação em madeira, incluso lançamento e adensamento, bem como a limpeza final da obra.
Esta etapa se perfaz por $0,18 \%$ (zero vírgula dezoito por cento) do percentual total para a execução da obra e possui um custo de R \$ 223,20 (duzentos e vinte e três reais e vinte centavos).

Tabela 13: Valores dos serviços finais e complementares da obra.

\begin{tabular}{|l|l|c|c|c|c|}
\hline ITEM & DESCRIÇÃO & UNID. & QUANT. & $\begin{array}{c}\text { PREÇO } \\
\text { UNIT. (R\$) }\end{array}$ & $\begin{array}{c}\text { PREÇO } \\
\text { TOTAL (R\$) }\end{array}$ \\
\hline $\mathbf{0 5}$ & COMPLEMENTARES & & $\mathbf{2 2 3 , 2 0}$ \\
\hline 5.1 & $\begin{array}{l}\text { Execução de passeio (calçada) em concreto 12 mpa, traço } \\
1: 3: 5 \text { (cimento/areia/brita), preparo mecânico, espessura 7cm, } \\
\text { com junta de dilatação em madeira, incluso lançamento e } \\
\text { adensamento. }\end{array}$ & $\mathrm{M}^{2}$ & 10,00 & 14,00 & 140,00 \\
\hline 5.2 & Limpeza final da obra. & $\mathrm{M}^{2}$ & 40,00 & 2,08 & 83,20 \\
\hline
\end{tabular}

Fonte: Autores, (2017).

Acima, a tabela 10, 11, 12 e 13 demonstra o custo para a execução da estação de tratamento de esgoto segundo a tabela disponibilizada pelo SINAPI.

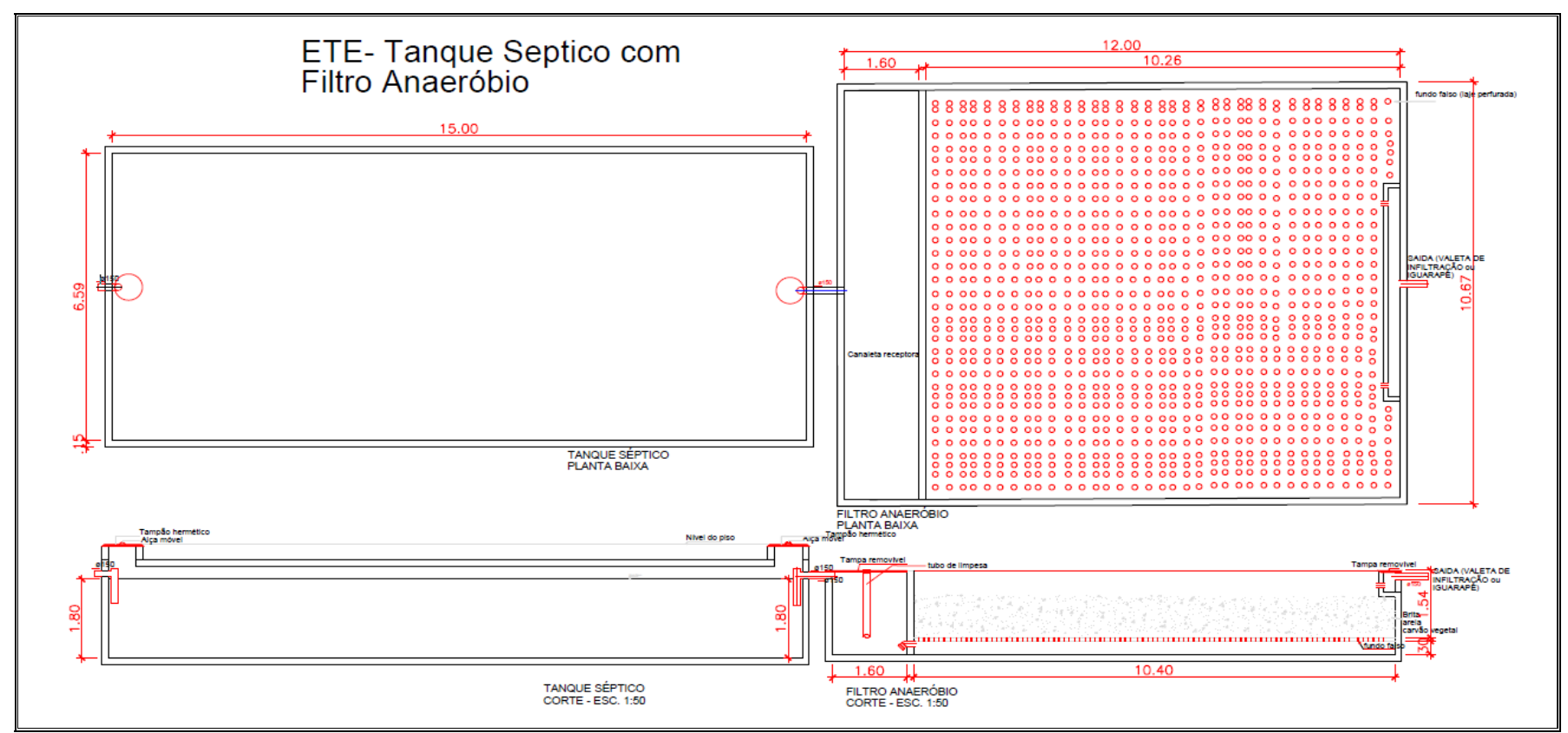

Figura 5: croqui do projeto de execução da ETE.

Fonte: Autores, (2017). 


\section{CONCLUSÃO}

A implementação da estação de tratamento de esgoto com filtro anaeróbio no Conjunto Ayapuá mostra-se como uma excelente alternativa para a diminuição do grande volume de esgoto não tratado que é despejado todos os dias nos mananciais daquela região. No mais, o tempo médio para a duração da obra, se implantada, é relativamente curto e tem relação direta com o custo de execução do projeto e sua posterior manutenção. Neste sentido existe correlação intrínseca entre o objetivo maior que é a diminuição da poluição na zona oeste de Manaus, especificamente no Conjunto Ayapuá com os benefícios trazidos pela implantação de uma ETE naquela parte específica da cidade.

Sabe-se que a escolha da ETE do novo milênio não se restringe apenas às exigências ambientais, de saúde pública, estéticas ou legais [10], desta forma, a escolha do local para a implantação da ETE pautou-se por tais questões. O referido local encontra-se de tal forma distante dos blocos residenciais do conjunto Ayapuá e toda a sua disposição não acarreta quaisquer prejuízos ou incomodo aos moradores. Frise-se que a implementação da ETE com filtro anaeróbio, nos moldes adotados neste artigo, possui custo notadamente inferior à maioria das políticas públicas que visem a remediação de danos ambientais decorrentes de despejo de resíduos em rios, lagos, igarapés ou outras bacias hidrográficas. Neste sentido, com a devida execução, a metodologia aplicada neste trabalho corresponde de forma clara e precisa aos objetivos determinados neste artigo.

Finalmente, com a implementação de mais uma ETE na cidade de Manaus, cumpre-se um papel importante no combate à poluição dos mananciais, que tem papel tão importante não apenas em termos regionais, mas com âmbito nacional e até internacional.

\section{REFERÊNCIAS}

[1] Tsutiya, Milton e Alem Sobrinho, Pedro. Coleta e Transporte de Esgoto Sanitário. São Paulo. Escola Politécnica da USP. $2^{\text {a }}$ Edição. 1999.

[2] Seiffert, M. E. B. Gestão Ambiental: instrumentos, esferas de ação e educação ambiental. São Paulo: Atlas, 2007b.

[3] Buitrón, G.; Gonzáles, A.; Wat. Sci. Tech. 1996, 34, 289.

[4] Von Sperling, Marcos - Introdução à qualidade das águas e ao tratamento de esgotos / Marcos von Sperling. - 2. ed Belo Horizonte: Departamento de Engenharia Sanitária e Ambiental. Universidade Federal de Minas Gerais; 1996.

[5] Tchobanoglous, G.; Burton, F.L.; Stensel, H.D. Wastewater engineering: treatment and reuse/ Metcalf \& Eddy, Inc. 4a ed. McGraw-Hill, New York, 2003

[6] Layrargues, P. P. Sistemas de gerenciamento ambiental, tecnologia limpa e consumidor verde: a delicada relação empresa-meio ambiente no ecocapitalismo. RAE - Revista de Administração de Empresas, São Paulo, v. 40, n. 2, abr./jun. 2000, p. $80-88$.

[7] Layrargues, P. P. O desafio empresarial para a sustentabilidade e as oportunidades da educação ambiental. In: LOUREIRO, C.F.B. (org.). Cidadania e meio ambiente. Salvador - BA: CRA, 2003, p. 95-110.
[8] ASSOCIAÇÃO BRASILEIRA DE NORMAS TÉCNICAS ABNT NBR 9648: Estudos de concepção de sistemas de esgoto sanitário. Rio de Janeiro, 1986.

[9] Biblioteca Didática de Tecnologias Ambientais, UNICAMP. Disponível em:

<http://www.fec.unicamp.br/ bdta/esgoto/esgotocaracteristicas.ht m>. Acesso em 10 de fevereiro de 2017.

[10] Kobiyama, M.; Mota, A.A. \& Corseuil, C.W. Recursos Hídricos E Saneamento. Curitiba: Ed. Organic Trading, 2008. $160 \mathrm{p}$.

[11] Associação Brasileira de Engenharia Sanitária e Ambiental, ABES seção ES. Disponível em: <http://abeses.org.br/drupaIBU/sites/default/files/arquivos/1_modulo_caracteristicas de esgotos_e normas.pdf>. Acesso em 10 de fevereiro de 2017.

[12] Pinheiro, A. V. Alternativas para destinação final do lodo gerado no tratamento de esgoto sanitário. 2012. $66 \mathrm{f}$ Dissertação (Graduação em Engenharia) - Curso de Engenharia Civil. Universidade Federal de Juiz de Fora, Minas Gerais.

[13] Jordão, E. P. e Pessôa, C. A. Tratamento de esgotos domésticos. Rio de Janeiro: ABES, 4. Ed. 2009.

[14] Duarte, A. C. L. Incorporação de lodo de esgoto na massa cerâmica para a fabricação de tijolos maciços: uma alternativa para a disposição final do resíduo. 2008. $109 \mathrm{f}$ Dissertação (Mestrado em Engenharia) - Curso de Engenharia Civil. Universidade Federal do Rio Grande do Norte, Natal.

[15] Chen, Y.; Chen, Y,-S.; Xy, O.; Zhou, O. Gu, G. Comparison between acclimated and unacclimated biomass affecting anaerobic-aerobic transformations in the biological removal of phosphorus. Process Biochemistry. V.40, p. 723-732, 2005.

[16] Ferreira, A. C.; Andreolli, C. V. Produção e características dos biosólidos. In: Uso e manejo do lodo de esgoto na agricultura, 1., 1999, Curitiba:. Anais... Curitiba: SANEPAR, 1999.

[17] Google maps, https://www.google.com.br/maps março de 2017.

[18] Instituto Brasileiro de Geografia e Estatística (IBGE). Estimativa populacional 2010. - Acesso em 25 de Fevereiro de 2017.INSTITUTO BRASILEIRO DE GEOGRAFIA E ESTATÍSTICA - IBGE. Disponível em $<$ http://cidades.ibge.gov.br/xtras/perfil.php?codmun=130260>. Acesso em 25 de fevereiro de 2017.

[19] PORTAL DO SANEAMENTO BÁSICO. Disponível em <https://www.saneamentobasico.com.br/portal/index.php/concess oes/quase-90-da-capital-de-manaus-nao-tem-saneamentobasico/>. Acesso em 28 de fevereiro de 2017.

[20] ASSOCIAÇÃO BRASILEIRA DE NORMAS TÉCNICAS. Projeto, Construção e Operação de Sistemas de Tanques Sépticos. NBR 7229/ 93. ABNT, Rio de Janeiro. 1993.

[21] ASSOCIAÇÃO BRASILEIRA DE NORMAS TÉCNICAS. Tanques sépticos - Unidades de tratamento complementar e disposição final dos efluentes líquidos - Projeto, construção e operação. NBR 13969/ 97. ABNT, Rio de Janeiro. 1997.

[22] Thiry-Cherques, Hermano Roberto. Modelagem de projetos. São Paulo: Atlas, 2002. p. 121-123. 